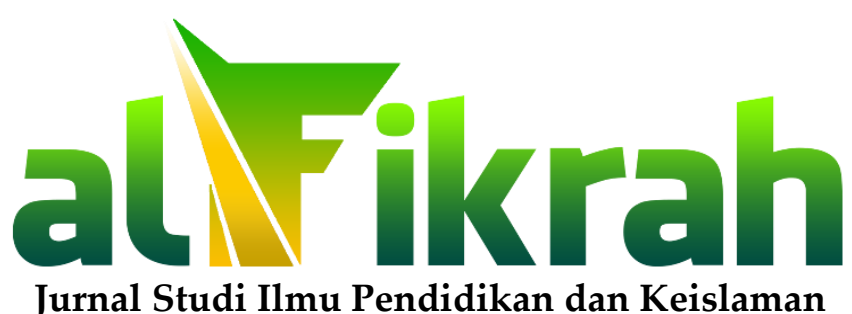

ISSN (Media Cetak) : 2620-4207 ISSN (Media Online) : 2620-4304

Volume 4, Nomor 1, Juni 2021

Terakreditasi Sinta Nomor: 200/M/KPT/2020

Diterbitkan Oleh : STAI Al-Hamidiyah Bangkalan

\title{
KONSEP PENDIDIKAN ISLAM PERSPEKTIF AZ-ZARNUJI SEBAGAI WAWASAN DALAM PEMBELAJARAN
}

\section{AZ-ZARNUJI'S PERSPECTIVE OF ISLAMIC EDUCATION AS INSIGHTS IN LEARNING}

\author{
Hayyul Mubarok ${ }^{1}$
}

STAI Al-Hamidiyah Bangkalan

mubarokhayyul@gmail.com

\begin{abstract}
Abstrak
IImu merupakan pengetahuan yang berasal dari pengamatan panca indera, juga bisa disebut empirik, IImu juga dapat berawal dari cara berfikir manusia dengan menggunakan rasio. Tapi ada istilah mengatakan IImu yang paling utama adalah IImu alam dan perbuatan yang paling mulia adalah menjaga hal atau kondisi diri. Pendidikan lsIam merupakan usaha dalam membangun dan meningkatkan sumber daya manusia (human resources), bersama dengan kesehatan (health) dan kesejahteraan sosial (welfare) melalui konsep lsIami. Pendidikan lsIam perspektif Az-Zarnuji merupakan rancangan kegiatan yang paling banyak berpengaruh terhadap perubahan perilaku manusia dan suatu masyarakat, serta menjadi model pembelajaran dalam pendidikan yang
\end{abstract}

${ }^{1}$ Dosen Tetap STAI Al-Hamidiyah Bangkalan 
efektif untuk menyiapkan masyarakat di masa depan. Sedangkan ruang lingkup Pendidikan Agama lsIam meliputi keserasian, keselarasan, dan keseimbangan antara hubungan manusia dengan Allah SWT, hubungan manusia dengan sesama manusia, dan ketiga hubungan manusia dengan dirinya sendiri, serta hubungan manusia dengan makhluk lain dan lingkungannya. Pada ruang lingkup inilah konsep Az-Zarnuji memiliki peran besar, sehingga melalui konsep yang ditawarkannya ada wawasan khusus di dalam pembelajaran.

Kata Kunci; Pendidikan, Az-Zarnuji, Pembelajaran

\begin{abstract}
Science is knowledge that comes from the observation of the five senses, can also be called empirical, Science can also start from the human way of thinking by using ratios. But there is a saying that the most important science is the natural science and the noblest action is to take care of one's own condition. Islamic education is an effort to build and improve human resources, along with health and social welfare through the Islamic concept. Az-Zarnuji's perspective Islamic education is the design of activities that have the most influence on changes in human behavior and a society, as well as being a learning model in effective education to prepare society for the future. While the scope of Islamic Religious Education includes harmony and balance between human relations with Allah SWT, human relations with fellow humans, and the third human relationship with himself, as well as human relations with other creatures and their environment. It is in this scope that the concept of Az-Zarnuji has a big role, so that through the concepts it offers there are special insights in learning.
\end{abstract}

Keywords: Education, Az-zarnuji, Learning. 


\section{Pendahuluan}

Konsep pendidikan lsIam mewadahi dari pengertian tujuan pendidikan yang diharapkan, yaitu memanusiakan manusia (Humanisis), yang mencakup aspek kemanusiaan seperti kecerdasan intelektual (IQ), kecerdasan emosi (EQ), kecerdasa spritual (SQ), seperti yang telah dicantumkan dalam UU No. 20 Tahun 2003. Bab II pasal 3. Pendidikan Nasional berfungsi mengembangkan kemampuan dan membentuk watak serta peradaban suatu bangsa yang bermartabat dan bertujuan untuk mengembangkan potensi peserta didik agar menjadi manusia yang beriman dan bertakwa kepada Tuhan Yang Maha Esa, berakhlak mulia, sehat, beriImu, cakap, kreatif, mandiri, dan menjadi warga negara yang demokratis yang baik. ${ }^{2}$

IImu merupakan cahaya bagi setiap manusia, untuk menjadi manusia yang sempurna, maka penting baginya untuk menuntut IImu sesuai kebutuhannya begitu pula dalam pendidikan lsIam juga memiliki fungsi sangat penting sebagai pembinaan dan penyempurnaan kepribadian serta mental peserta didik, karena pendidikan lsIam memiliki dua aspek penting, yaitu aspek pertama yang ditujukan kepada jiwa atau pembentukan kepribadian anak, dan kedua ditujukan pada pikiran, yakni, pengajaran agama lsIam.

Aspek pertama dari Pendidikan 1sIam adalah yang ditujukan kepada jiwa atau pembentukan kepribadian. Artinya melalui pendidikan lsIam anak didik diberikan keyakinan terhadap Allah SWT. ${ }^{3}$ Sedangkan IImu adalah suatu pengetahuan yang berasal dari pengamatan panca indera, juga bisa disebut empirik, lImu juga dapat berawal dari cara berfikir manusia dengan menggunakan rasio. ${ }^{4}$ Tapi ada istilah me-ngatakan IImu yang paling utama adalah IImu hal, dan perbuatan yang paling mulia adalah menjaga hal atau kondisi diri. Yang dimaksud dengan IImu hal yaitu lImu yang selalu diperlukan dalam melaksanakan agama yaitu lImu

${ }_{2}^{2}$ Sisdiknas, Sistem Pendidikan Nasional,No. 20 Tahun 2003, (Jakarta: Rhusty Publisher, 2009), 5 .

${ }^{3}$ Rahmat Hidayat, Ilmu Pendidikan Islam,(Medan:LPPPI, 2016),25.

${ }^{4}$ Beni Ahmad Saebani, Ilmu Akhlak,( Bandung:CV Pustaka Setia,2010), 17. 
usuluddin dan IImu figh, dua IImu tersebut menjadi hal pokok bagi ummat lsIam untuk menjalani kehidupan yg sesuai dengan ajaran agama lsIam. ${ }^{5}$

Pendidikan adalah sebuah usaha dalam membangun dan meningkatkan sumber daya manusia (human resources), bersama dengan kesehatan (health) dan kesejahteraan sosial (welfare). Sumber daya manusia tidak akan berkembang dan maju tanpa pendidikan. ${ }^{6}$ Pendidikan merupakan rancangan kegiatan yang paling banyak berpengaruh terhadap perubahan perilaku manusai dan suatu masyarakat, dan menjadi model rekayasa sosial yang efektif untuk menyiapkan masyarakat di masa depan.

Pendidikan bertujuan untuk mengembangkan potensi peserta didik agar menjadi manusia yang beriman dan bertakwa kepada Tuhan Yang Maha Esa, berakhlak mulia, sehat, berilmu, cakap, kreatif, mandiri, dan menjadi warga negara yang demokratis serta bertanggung jawab. Tujuan Pendidikan Nasional tersebut sebenarnya sangat relevan dengan tujuan pendidikan lsIam, yakni membentuk dan membangun manusia yang sempurna lahir batin yang disebut dengan al-insan al-kamil yang bersumber kepada Al-Qur'an dan Hadist. ${ }^{7}$

Dalam agama lsIam mencari IImu adalah hak wajib bagi setiap muslim. ${ }^{8}$ Atas pandangan tersebut tidak jarang seorang muslim menyadari hal itu, bahkan tidak semerta-merta diabaikan begitu saja berbagai hal yang terjadi pada setiap peserta didik, adakalanya, Ia mencari IImu karena tuntutan orang tua ada juga yang memang berangkat dari kemauan sendiri dan pergaulan seorang temannya, menjadi hal menarik ketika suatu konsep IImuan cukup memadai untuk menunjang semangat belajar peserta didik. Dalam ruang lain juga dibutuhkan pengembangan atas perilaku sebagai bentuk evaluasi dari orang lain.

Motivasi adalah perubahan energi dalam diri seseorang yang ditandai dengan munculnya "feeling". 9 Tidak jauh beda dengan motivasi pendidikan lsIam mengingat berbagai realita akhir zaman yang cukup

${ }^{5}$ Syekh Az Zarnuji, Ta'lim wa Muta'allim Pedoman Belajar Pelajar dan Santri,(Surabaya: ALHIDAYAH,2005), 1.

${ }^{6}$ Abd Basir, Pendidikan Keluarga Qur'ani, (Banjarmasin: Aswaja Pressindo, 2003), 1.

7Ibid, 34.

8Syekh Az Zarrnuji, Ta'lim wa Muta'allim, (Magelang: Maktabah Menara Kudus, 1963), 11. 'Sardiman A.M. Interaksi dan motivasi Belajar Mengajar, (Jakarta: PT RAJA GRAFINDO PERSADA, 2012), 73. 
jauh dari tatanan-tatanan agama yg sebenarnya, penting bagi setiap proses pembelajaran untuk menyadari akan hal itu dengan menetapkan ajaran salafi yang masih eksis sampai sekarang untuk memperoleh IImu yang barokah dan bermanfaat. Konsep IImuan Timur Tengah yakni karangan Syaikh Burhanul lsIam Az-Zarnuji yang bernama Ta'limul mutaallim sebagai acuan agar peserta didik semangat dalam mencari IImu, melihat dari muqoddimah Az-Zarnuji dalam kitabnya, Beliau menceritakan tujuannya dalam menulis Ta'limull mutaallim, bahwa Ia melihat begitu banyak penuntut IImu yang bersungguh-sungguh di zamannya, namun, tidak sampai pada IImunya, tidak dapat mengambil manfaat darinya dikarenakan meninggalkan syarat-syarat dalam mencari IImu. ${ }^{10}$

\section{Pembahasan}

\section{Konsep Pendidikan lsIam}

Pendidikan Agama lsIam mempunyai peran aktif dalam menciptakan generasi yang mampu berinteraksi sosial dengan baik, sebaliknya aspek sosial memberikan informasi ke dalam dunia pendidikan tentang nilai-nilai yang berlaku di masyarakat. Pendidikan Agama lsIam mengenalkan kepada peserta didik tentang nilai-nilai yang terdapat dalam Agama lsIam agar kelak IImu yang dimiliki dan kemudian diamalkan sesuai dengan nilai-nilai dan ajaran keagamaan meskipun tidak secara mayoritas masyarakat Indonesia adalah beragama lsIam. Akantetapi sebuah nilai pendidikan lsIam bisa dianggap berhasil ketika peserta didik mempunyai kemampuan dan potensi untuk dimanfaatkan oleh dirinya, masyarakat, agama, bangsa, dan negara.

Keberhasilan dalam pendidikan agama lslam tidak hanya bisa ditentukan dengan struktur nilai yang disimbolkan dengan angka, melainkan lebih ditentukan oleh kehidupan interaksi sosial seharihari yang terjadi di sekolah, baik antar masyarakat, sekolah, maupun antara sekolah dengan masyarakat sekitar dengan nilai-nilai keisIaman. Oleh karena itu konsep-konsep lsIami mempunyai kontribusi penting bagi Pendidikan Agama lsIam dalam kaitannya dengan penerapan agama dalam kehidupan bermasyarakat.

${ }^{10}$ Imam Az Zarnuji, Pentingnya Adab Sebelum Ilmu, (Solo: PT AQWAM MEDIA PROFETIKA, 2019), 5. 
Agama merupakan salah satu aspek penting dalam kehidupan masyarakat yang perlu dipelajari oleh antropolog ataupun para IImuwan sosial lainnya. Di dalam kehidupan masyarakat, agama muncul karena sifat ketauhidan masyarakat tersebut. Oleh karena itu agama perlu dipelajari dan dihayati oleh manusia karena kebutuhan manusia terhadap Sang Maha Pencipta. Di dalam agama dijumpai ungkapan materi dan budaya dalam tabi'at manusia serta dalam sistem nilai, moral, etika, kajian agama, khususnya Agama lsIam merupakan kebutuhan hidup bagi masyarakat Indonesia, khususnya mayoritas. Oleh karena itu, kajian agama seperti lsIam, tidak hanya sebatas konsep saja, teori dan aspek-aspek kehidupan manusia beserta hukumnya, tapi harus dihayati dan direnungi untuk diamalkan dalam kehidupan manusia.

Ide-ide keagamaan dan konsep-konsep keagamaan itu tidak dipaksa oleh hal-hal yang bersifat fisik tapi bersifat rohani. Karenanya agama merupakan suatu institusi ajaran yang menyajikan lapangan ekspresi dan implikasi yang begitu halus dan berbeda dengan suatu konsep hukum ataupun undang-undang yang dibuat oleh masyarakat. Sasaran langsung atau obyek material pendekatan agama ialah dunia pendidikan. Pendidikan agama adalah suatu persekutuan hidup baik dalam lingkungan sempit atau luas yang unsur konstitutif utamanya adalah agama atau nilainilai keagamaan.

Kelompok-kelompok pelajar Pendidikan Agama lsIam terdiri dari komponen-komponen konstitutif. Misalnya kelompok keagamaan atau institusi-institusi religius yang mempunyai ciri tertentu menurut peraturan dan norma-norma yang ditentukan oleh agama. Para pelajar Pendidikan Agama yang seperti itu akan terus disoroti struktur dan fungsinya, pengaruhnya terhadap siswa dan siswi itu sendiri dan atas stratifikasi sosial khususnya. Hal itu disebabakan oleh adanya kesadaran kelompok religius yang mempunyai sifat tersendiri, untuk mengkaji perubahanperubahan yang disebabkan oleh agama, baik yang positif maupun yang negatif. Seperti kerukunan antar golongan agama dan konflik-konflik yang sering terjadi. ${ }^{11}$

Bila dikatakan bahwa yang menjadi sasaran dalam konsep pendidikan Agama lsIam adalah pelajar, sesungguhnya yang dimaksud bukanlah agama sebagai suatu sistem (dogma dan moral), tetapi agama

${ }^{11}$ Tharaba. 2016. Sosiologi Agama. Malang: Madani. 
sebagai fenomena sosial, sebagai fakta sosial yang dapat dilaksanakan dan dialami oleh siswa dan siswi. IImu ini hanya menkonstatasi akibat empiris kebenaran-kebenaran supra empiris, yaitu yang disebut dengan istilah kelompok agama, dan itulah sasaran langsung, sedangkan yang hendak dicari dalam fenomena agama itu adalah dimensi langkah dan caracaranya. ${ }^{12}$

Sampai seberapa jauh agama dan nilai-nilai keagamaan memainkan peranan dan berpengaruh atas eksistensi dan operasi masyarakat manusia. Lebih konkrit misalnya, seberapa jauh unsur kepercayaan mempengaruhi pembentukkan kepribadian pemeluk-pemeluknya, ikut menciptakan jenisjenis kebudayaan, mewarnai dasar dan haluan negara, memainkan peranan dalam memunculkan strata sosial. Jadi hal-hal tersebut dalam contoh di atas yang berkaitan erat dengan masalah agama.

Pemaknaan pembelajaran pendidikan agama lsIam merupakan bimbingan menjadi muslim yang tangguh dan mampu merealisasikan ajaran Pendidikan Agama lsIam dalam kehidupan sehari-hari sehingga menjadi insan kamil. Untuk itu penanaman Pembelajaran berkonsep pendidikan lsIam sangat penting dalam membentuk dan mendasari peserta didik. Dengan penanaman pembelajaran PAI sejak dini diharapkan mampu membentuk pribadi yang kokoh, kuat dan mandiri untuk berpedoman pada agama lsIam. ${ }^{13}$

Pendidikan adalah bimbingan secara sadar oleh pendidik kepada terdidik terhadap perkembangan jasmani dan rohani si terdidik menuju kepribadian yang lebih baik, yang pada hakikatnya mengarah pada pembentukan manusia yang ideal. Manusia ideal adalah manusia yang sempurna akhlaqnya, yang nampak dan sejalan dengan misi kerasulan Nabi Muhammad saw, yaitu menyempurnakan akhlaq yang mulia. Agama lsIam adalah agama universal yang mengajarkan kepada umat manusia mengenai berbagai aspek kehidupan baik kehidupan yang sifatnya duniawi maupun yang sifatnya ukhrawi. Salah satu ajaran lsIam adalah mewajibkan kepada umatnya untuk melaksanakan pendidikan, karena dengan pendidikan manusia dapat memperoleh bekal kehidupan yang baik dan terarah.

\footnotetext{
${ }^{12}$ Jamaluddin. 2015. Agama dan Konflik Sosial. Bandung: CV Pustaka Setia.

${ }^{13}$ Muhaimin, Peradigma Pendidikan Islam, 183.
} 
Pendidikan dalam pandangan yang sebenarnya adalah suatu sistem pendidikan yang memungkinkan seseorang dapat mengarahkan kehidupannya sesuai dengan cita-cita lsIam, sehingga dengan mudah ia dapat membentuk hidupnya sesuai dengan ajaran lsIam. Pengertian itu mengacu pada perkembangan kehidupan manusia masa depan tanpa menghilangkan prinsip-prinsip lsIami yang diamanahkan oleh Allah kepada manusia, sehingga manusia mampu memenuhi kebutuhan dan tuntutan hidupnya seiring dengan perkembangan iptek.

Ruang lingkup Pendidikan Agama lsIam meliputi keserasian, keselarasan, dan keseimbangan antara hubungan manusia dengan Allah SWT, hubungan manusia dengan sesama manusia, dan ketiga hubungan manusia dengan dirinya sendiri, serta hubungan manusia dengan makhluk lain dan lingkungannya. Ruang lingkup Pendidikan Agama lsIam juga identik dengan aspek-aspek Pengajaran Agama lsIam karena materi yang terkandung di dalamnya merupakan perpaduan yang saling melengkapi satu dengan yang lainnya. ${ }^{14}$

Apabila dilihat dari segi pembahasannya maka ruang lingkup Pendidikan Agama lsIam yang umum dilaksanakan di sekolah adalah, a) pengajaran keimanan. Pengajaran keimanan berarti proses belajar mengajar tentang aspek kepercayaan, dalam hal ini tentunya kepercayaan menurut ajaran lsIam, inti dari pengajaran ini adalah tentang rukun lsIam. Selanjutnya pengajaran akhlak. b) Pengajaran akhlak adalah bentuk pengajaran yang mengarah pada pembentukan jiwa, cara bersikap individu pada kehidupannya, pengajaran ini berarti proses belajar mengajar dalam mencapai tujuan supaya yang diajarkan berakhlak baik. c) Pengajaran ibadah. Pengajaran ibadah adalah pengajaran tentang segala bentuk ibadah dan tata cara pelaksanaannya, tujuan dari pengajaran ini agar siswa mampu melaksanakan ibadah dengan baik dan benar. d) Pengajaran fiqih. Pengajaran fiqih adalah pengajaran yang isinya menyampaikan materi tentang segala bentuk-bentuk hukum lsIam yang bersumber pada AlQuran, sunnah, dan dalil-dalil syar'i yang lain. e) Pengajaran Al-Quran. Pengajaran Al-Quran adalah pengajaran yang bertujuan agar siswa dapat membaca Al-Quran dan mengerti arti kandungan yang terdapat di setiap ayat-ayat Al-Quran. Akan tetapi dalam prakteknya hanya ayat-ayat tertentu yang di masukkan dalam materi Pendidikan Agama lsIam yang disesuaikan dengan tingkat pendidikannya. f) Pengajaran sejarah lsIam.

14 Ibid. 
Tujuan pengajaran dari sejarah lsIam ini adalah agar siswa dapat mengetahui tentang pertumbuhan dan perkembangan agama lsIam dari awalnya sampai zaman sekarang sehingga siswa dapat mengenal dan mencintai agama lsIam. ${ }^{15}$

Pendidikan lsIam sebagai suatu proses pengembangan diri. Manusia adalah makhluk paedagogik, yaitu makhluk Allah yang dapat dididik dan dapat mendidik. Potensi ini merupakan pemberian Allah berupa akalpikiran, perasaan, nurani, yang akan dijalankan manusia baik sebagai makhluk individu maupun sebagai makhluk yang bermasyarakat. Potensi yang besar tidak akan bisa kita manfaatkan jika kita tidak berusaha untuk mengaktifkan, mengembangkan dan melatihnya. Hal itu membutuhkan sebuah proses yang akan memakan waktu, tenaga bahkan biaya, tetapi mengingat potensi yang luar biasa yang kita akan raih hal itu tidak ada artinya apa-apa. Jadi pendidikan adalah proses untuk mengembangkan potensi diri.

\section{Konsep Pendidikan Islam Perspektif Az-Zarnuji}

Konsep Az-Zarnuji merupakan konsep yang membahas tentang nasihat-nasihat yang baik, tentang sikap yang harus dimiliki orang dalam mencari IImu, kitab ini juga diakui sebagai karya yang sangat diperhitungkan di Negara Timur Tengah maupun Negara Barat, salah satu Negara Barat yang pencetaknya adalah Negara Jerman pada tahun $1709 \mathrm{M}$ oleh Musio Ralandus dan Musio Caspari pada tahun 1838.16 Adapun konsep-konsep Az-Zarnuji tertuang dalam karya monumentalnya, yakni kitab Ta'limul Muta'allim Thariq At-Taallim. Keistimewaan pada buku ini terletak pada materi yang di kandungnya, meskipun kecil dengan judul yang seakan-akan hanya membahas tentang IImu dalam belajar, namun esensinya mencakup tujuan, prinsip-prinsip dan strategi belajar yang didasari oleh moral religius.

Terbukti dalam muqaddimah pentahqiq, beliau mengemukakan hasil pengamatannya tentang seseorang yang telah mencari lImu di zamannya, yang bersungguh-sungguh, tetapi tidak sampai kepada IImu tersebut, yakni tidak mendapatkan manfaat dari IImu yang telah mereka dapatkan, dan terhalang dari buahnya IImu, (mengamalkan dan menyebarkannya).

\footnotetext{
${ }^{15}$ Muhaimin, Peradigma Pendidikan Islam, 183.

16Imam AzZarnuji, Ta'limul Muta'allim Pentingnya Adab Sebelum Ilmu, 17.
} 
Pada konteks lain mereka juga keliru dalam menempuh jalan (mencari IImu) dan meninggalkan syarat-syaratnya, mengutip dari bab pertama dalam kitab Ta'limul Mutaallim dan barang siapa yang salah dalam menempuh jalan maka akan tersesat, dan tidak aka meraih tujuan, baik sedikit maupun banyak. Yakni seorang yang tidak menempuh jalan mencari IImu yang tidak sesuai dengan syarat-syaratnya, maka ia akan salah dalam menempuhnya. ${ }^{17}$

Adapun konsep- konsep Az-Zarnuji sebagai berikut:

\section{Petama; Definisi IImu dan figh beserta keutamaannya}

Az-Zarnuji telah memulai konsep definisi IImu dan figh beserta keutamaannya dengan menuturkan hadis Rasulullah SAW. Rasulullah SAW. bersabda

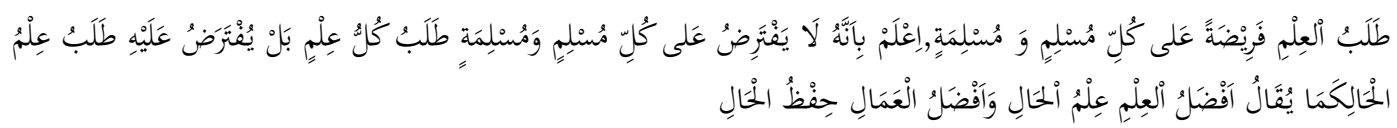

Artinya: Mencari IImu itu diwajibkan bagi setiap muslim laki-laki dan perempuan, misalnya, mempelajari tentang keesaan Allah Swt. Beserta sifat-sifatnya, lImu tentang shalat dan thaharah.

Namun menurut Az-Zarnuji orang lsIam itu tidak wajib mengetahui semua IImu secara wajib ain. Akantetapi yang diwajibkan bagi orang lsIam adalah mencari IImu yang berhubungan dengan keperluan manusia seperti (shalat, kufur, zakat, iman dan lain-lain), seperti yang telah dikatakan oleh ulama' IImu yang paling utama adalah IImu hal, dan paling utamanya setiap amal adalah menjaga hal di wajibkan pula baginya untuk mempelajari IImu tawakkal, khassyiyah, rida dan inabah karena hal itu terjadi di setiap keadaan. ${ }^{18}$

\section{Kedua; Niat ketika belajar}

Niat ketika belajar dan tujuannya, menurut Az-Zarnuji niat yang benar adalah niat mencari keridlaan Allah SWT. Pentingnya niat ketika belajar pada masa-masa menuntut IImu, karena niat merupakan sesuatu

\footnotetext{
${ }^{17} \mathrm{Ibid}, 18$.

${ }^{18}$ Syekh AZ Zarnuji, Ta'limul Muta'allim, 1-3.
} 
yang fundamental dalam segala hal. Seperti yang telah di Sabdakan Nabi Muhammad SAW.

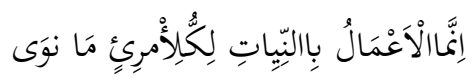

Artinya: Sesungguhnya sahnya segala amal itu tergantung pada niatnya. Dalam menuntut IImu sebaiknya seorang pelajar berniat mencari ridha Allah SWT, mengharap kebahagiaan akhirat ${ }^{19}$

Konsep uraian tersebut juga ditujukan pada niat menghilangkan kebodohan dari dirinya sendiri dan dari orang-orang bodoh, menghidupkan agama, dan melestarikan lsIam, karena sesungguhnya kelestarian lsIam hanya dapat dipertahankan dengan IImu, dan perilaku zuhud serta taqwa tidaklah sah dengan kebodohan. ${ }^{20}$

Konteks niat di sini dijadikan sebagai pedoman bahwa segala sesuatu jika berangkat dari niat yang sungguh-sungguh maka hasilnya akan sungguh-sungguh pula. Dentensinya, seorang yang ingin melakukan sesutu pastinya ia merencanakan sebelumnya. Rencana sebelumnya itu merupakan bagian dari niat. Akan tetapi niat itu ada dua hal antara sungguh-sungguh atau hanya sekadar niat saja tanpa ada tindakan. Begitu pula dalam dunia pendidikan. Di jaman sekarang ini banyak peserta didik, pelajar, dan aktivitas pembelajaran baik formal maupun non formal yang hanya ikut-ikutan saja tapa menanamkan niat yang sungguh-sungguh, sehingga tidak ada hasilnya.

Niat dalam pendidikan lsIam perspektif Az-Zarnuji di sini bukan hanya niat di dalam hati saja, melainkan harus disertakan dengan tindakannya. Sebab deskripsi atas pernyataannya bukan semata-mata hanya "ingin" namun disertakan "bertindak". Konteks "ingin" di sini hanya berada di seputar perasaan saja, sedangkan "bertindak" melakukan sesuatu dengan gerakan untuk mencapi dari keinginan itu sendiri.

\section{Ketiga; Tata Cara Memilih IImu, Guru, dan Teman}

Adapun tata cara memilih IImu, guru, dan teman; 1) Seorang hendaknya memilih IImu yang terbaik dan IImu yang dibutuhkan dalam

\footnotetext{
${ }^{19}$ Ibid, 10.

${ }^{20}$ Imam AzZarnuji, Pentingnya Adab Sebelum Ilmu, 48.
} 
kehidupan agamanya pada waktu itu, ia harus mendahulukan IImu tauhid dan ma'rifat. 2) Seorang hendaknya memilih guru yang wara', jujur, alim dan penyabar. Adapun memilih guru hendaknya dapat memilih seorang guru yang benar benar alim (pandai), lebih wara' dan yang lebih tua. 3) Seorang hendaknya memilih teman yang sungguh-sungguh wara' memiliki tabi'at yang baik mudah menjauhi sifat malas dan sebaliknya hendaknya seorang penuntut IImu menjauhi orang yang pemalas, suka menganggur, banyak bicara suka merusak dan menfitnah. ${ }^{21}$

Sebelum diuraikan terlalu jauh perlu kiranya diketahui apa yang melatarbelakangi persepsi tersebut. Seorang muslim tidaklah wajib mempelajari semua lImu yang ada di dunia ini, akan tetapi wajib mempelajari IImu yang dibutuhkan dalam kehidupannya. Dalam memilih IImu harus medahulukan mempelajari IImu Tauhid, agar kita biasa mengenali segala asal-usul adanya alam semesta ini. Selanjutnya IImu yang berada dalam ruang lingkup ibadah, sebab ibadah di sini bagian dari bentuk kebutuhan manusia dalam menjalankan kehidupannya sehari-hari, dan yang terakhir yaitu IImu yang menunjang kehidupan sehari-hari, misalkan IImu tentang duniawi.

Pada konteks yang lain, dalam memilih IImu dan mempelajarinya tentu butuh seorang guru, sebab guru sosok penting yang akan menjadi perantara bagi manusia. Dalam perspektif Az-Zarnuji hendaklah memilih IImu yang paling berilmu, wara, dan yang lebih tua. Konteks "tua" di sini bukan dari usia, tapi dari seberapa jauh ia mendalami IImu, dan seberapa jauh Ia mempelajarinnya, sehingga dapat menerima pengetahuan yang benar-benar akurat.

Selanjutnya memilih teman dalam dunia pendidikan lsIam (dalam proses pembelajaran). Dalam memilih teman seharusnya hendak berhatihati agar tidak terjerumus ke hal-hal yang buruk. Memilih teman dalam perspektif Az-Zarnuji yang pertama harus takwa, jujur, bisa menjaga amanah dengan baik, dan bisa mengajak ke hal yang positif. Segala bentuk tersebut bukan melarang untuk berteman dengan orang yang berperilaku buruk, namun jika seorang tidak mampu menjaga keberadaannya, khawatir di kemudian hari akan terjerumus melakukan hal yang buruk pula.

${ }^{21}$ Ibid,16-17. 


\section{Keempat; Menghormati lImu dan Ahlinya}

Penting diketahui bahwa seorang penuntut IImu tidak akan memperoleh lImu dan tidak dapat mengambil manfaat dari IImu itu kecuali dengan menta'dzimkan lImu dan ahlinya juga harus dimuliakan. ${ }^{22}$

Guru sebagai penuntun dalam menggapai pengetahuan sudah seharusnya bagi pelajar untuk hormat dan mentaati perintahnya. Imam Zarnuji menyampaikan ucapan Sayyidina Ali RA.

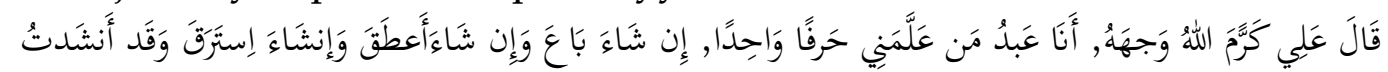

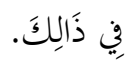

Artinya: Sayyidina Ali berkata: Saya merupakan budak dari seseorang yang mengajariku walau sehuruf, bagaimanapun Ia menghendaki menjual, membebaskan atau menetapkan jadi budak, saya akan tetap terima dengan hal itu. ${ }^{23}$

Ali merupakan sosok tauladan bagi penuntut lImu sebagai semangat memperoleh IImu yang berbaidah. Sosok ali begitu antusias dan semangat menghormati seorang guru, dia mengatakan walaupun "satu huruf" tetap harus dihormati dan dijadikan sebagai guru.

Sedikit bertolak belakang dengan kasus yang sering terjadi di jaman sekarang ini, tidak sedikit dari pendidik yang berprosesi sebagai guru atau guru yang notabeninya suka rela diancam bahkan dianiaya dituntut kepengadilan oleh orang tua wali atau oleh pelajar itu sendiri. Dari sini perlu adanya pembahasan ulang mengenai cara menghormati guru dengan baik dan santun supaya pencapaian menuntut IImu dapat diperoleh dengan baik dan sempurna.

Di sisi lain bentuk ketaatan dalam konsep perpektif lslam hal-hal yang dilakukan oleh seorang guru bagian dari tindakan demi muridmuridnya, bukan semata-mata untuk melakukan kekerasan. Banyak salah kaprah dalam memaknai dan memahami tindakan tersebut. Pada dasarnya, menghormati IImu dan ahlinya (guru) bagian dari keharusan yang dilakukan oleh peserta didik dan orang tua didiknya. Agar apa yang didapatkan selama belajar bisa bermanfaat dan berkah.

22Syekh AZ Zarnuji, Ta,limul Mutaallim, 24.

${ }^{23}$ Ibid, 24. 


\section{Kelima; Kesungghuhan dan Ketekunan dalam Mencari lImu Kesungguhan}

Suatu yang lumrah dan menjadi kebiasaan sebab dan akibat suatu perbuatan berdampak pada tahapan berikutnya. Dalam menuntut IImu atau menggapai cita-cita harus selalu disertai dengan kegigihan dan kesungguhan serta ketekunan dalam berusah. Tidak lepas dari itu, menuntut IImu bukan suatu yang remeh juga bukan suatu yang rumit melaikan perlu adanya kesungguhan agar mampu memperoleh hasil yang maksimal. Imam al-Zarnuji menyebutkan dalam kitabnya Ta'lim alMuta'allim:

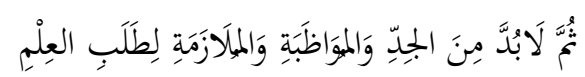

Artinya: Seharusnya penuntut IImu selalu rajin, bersungguh-sungguh dan terus menerus (intens) untuk menuntut IImu.

Dari pernyataan tersebut secara tekstual menunjukkan yang harus digunakan oleh seorang dalam menuntut IImu, maka konteks menuntut IImu adalah bagian dari Jihad atau berjuang di jalan Allah sehingga sangat terasa Az-Zarnuji menggunakan teks sangat kontektual sekali seakan langsung berlandaskan sumber. Di sisi lain harus ada kesungguhan seseorang yang menuntut IImu (muta'allim), fungsi atau profesi dari seorang yang menuntut IImu yaitu sebagai subyek, tidak akan terlaksana dengan baik proses kegiatan belajar mengajar jika tidak ada kesungguhan dan keseriusan subyek, yang pertama ini merupakan suatu keharusan dalam terlaksananya untuk memperoleh IImu.

Selanjutnya kesungguhan dari seorang guru. Fungsi dari seorang guru sendiri yaitu sebagai upaya penyambung tali pengetahuan karena tradisi keilmuan di dalam lslam khususnya tidak dapat dipungkiri dengan adanya sanad kesinambungan suatu IImu. Sehingga untuk mendapatka IImu dan pengetahuan yang luas harus memilih dan mencari guru yang semangat dan ikhlas mengajar serta mendidik. Karena jika seorang guru tidak penuh semangat dan keilkhlasan dalam menyampaikan IImunya juga tidak mungkin bagi seorang yang menuntut IImu memperoleh pengetahuan yang luas dan sempurna.

Di sisi lain pula dukungan dari keluarga juga cukup urgen dalam kemajuan pendidikan untuk memperoleh banyak pengetahuan, di samping orang tua sebagai pengasuh namun juga sebagai guru. Sehingga tiga pilar tadi yang disebut di atas sangat penting sekali untuk diterapkan dalam 
perjalanan hidup menuntut IImu antara kesungguhan dan semangat pelajar, guru dan orang tua.

\section{Ketekunan}

Az-Zarnuji menjelaskan selain semangat tinggi harus juga pelajar atau seseorang yang menuntut IImu harus memiliki ketekunan dalam belajar, beribadah dan berbakti, karena tanpa ketekunan seseorang tidak akan sampai mampu menyelesaikan dan memperoleh 1Imu. Az-Zarnuji menuturkan:

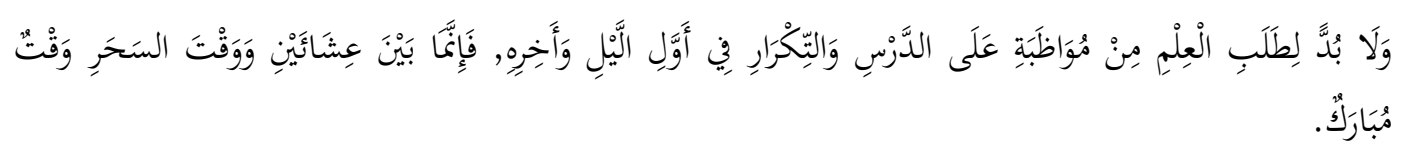

Artinya: Maka hendaknya bagi pelajar supaya memiliki waktu tertentu untuk belajar dan mengulang-ngulang pada awal malam dan akhir malam, maka sesungguhnya di antara magrib dan isya serta waktu sahur yaitu merupakan waktu yang penuh keberkahan.

Pernyataan Az-Zarnuji memuat beberapa keterangan, di antaranya; pertama tekun dalam belajar dan mengulang-ngulang mata pelajaran. kedua, waktu khusus yang penuh dengan keberkahan dan mudah dalam memperoleh pengetahuan yaitu pada waktu di antara maghrib dan isya' serta pada waktu sahur. ${ }^{24}$ Az-Zarnuji menyampaikan syair:

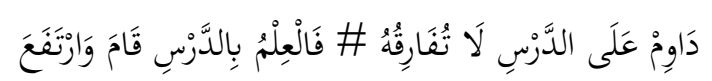

Artinya: Biasakanlah selalu belajar jangan sampai kamu meninggalkannya, karena IImu itu dengan belajar bisa tetap dan bertambah.

Pesan dari syair ini, yaitu bagi pelajar untuk selalu istiqomah dan selalu mengulang pelajaran, karena pelajaran itu akan selalu nempel di hati dan pikiran seseorang dengan selalu dipelajari dan diulang-ulang, serta IImu pengetahuan yang diperoleh akan selalu bertambah seiring dengan ketekunan penuntut $1 \mathrm{Im} u .^{25}$

\footnotetext{
${ }^{24} \mathrm{Ibid}, 40$.

${ }^{25} \mathrm{Ibid}, 40$.
} 


\section{Cita-cita luhur}

Az-Zarnuji mengutip dalam sebuah hadis Nabi:

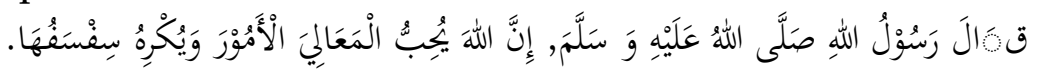

Artinya: Bahwa sesungguhnya Allah menyukai terhadap keluhuran suatu perkara, dan sebaliknya Allah tidak menyukai suatu yang remeh.

Kemudian Az-Zarnuji menjelaskan:

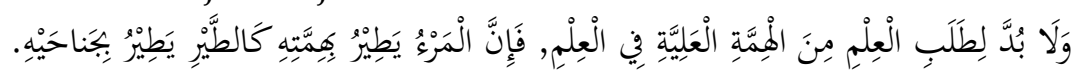

Artinya: Dan seharusnya bagi pelajar memilki cita-cita dan keinginan yang tinggi dalam masalah IImu, karena manusia itu bisa terbang dengan citacitanya seperti burung terbang dengan kedua sayapnya. ${ }^{26}$

Semua yang telah diupayakan oleh pengajar sebagai usaha untuk memperoleh pengetahuan harus selalu ditekuni diatur dengan menyusun waktu yang baik. Tetapi di samping itu supaya target jelas harus diikuti juga keinginan dan cita-cita tinggi yang luhur, agar apa yang telah diupayakan menjadi suatu manfaat bagi kehidupan di masa mendatang serta dapat dirasakan oleh orang lain.

\section{Keenam; Permulaan belajar}

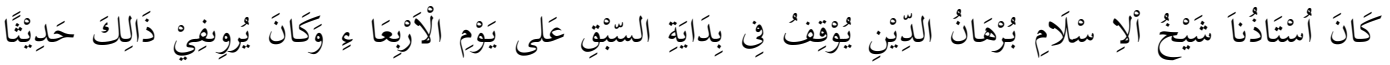

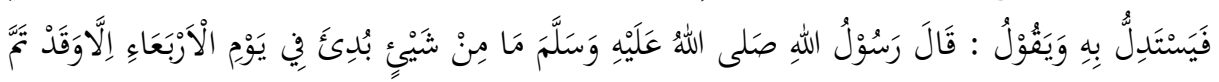

Artinya: Az-Zarnuji telah bercerita mengenai gurunya yang bernama Syaikhul lsIam Burhanuddin, yang menetapkan suatu ketentuan dalam permulaan belajar, yaitu pada hari rabu. Dalam hal ini Az-Zarnuji juga menyesuaikan dengan sebuah hadist, dan beliau menjadikan hadist tersebut sebagai landasan dalam konsepnya. "Tiada sesuatu yang dimulai di hari rabu, melainkan akan menjadi sempurna." 27 Dalam hadist ini bisa dijadikan pegangan untuk para menuntut IImu guna meraih IImu yang barokah dari anjuran Rasulullah SAW.

Hari Rabu di sini mempunyai keistimewaan jika ditinjau dari muatan historisnya. Pada muatan historisnya, hari Rabu tersebut sangat tepat untuk memulai menuntut IImu, karena sudah menjadi petuah yang

\footnotetext{
${ }^{26}$ Ibid, 42-44.

27Syekh Az zarnuji, Ta'limul Muta'allim, 54.
} 
ditetapkan seorang guru terhadap muridnya. Maka dari itu sudah menjadi ketentuan yang harus dipatuhi. di sisi lain jika ditalaah secara mendalam, hari Rabu merupakan hari di mana Allah menciptakan cahaya.

\section{Ketujuh; Tawakkal}

Dalam konsep tawakkal menurut Az-Zarnuji dikatakan bahwa, seorang penuntut IImu tidak diperkenankan memikirkan urusan rezeki dan menyibukkan hatinya dengan urusan itu. Telah diriwayatkan oleh AlImam Abu Hanifah dari Abdillah bin Hasan Az-Zubaidi sahabat Rasulullah SAW. Rasulullah telah bersabda:

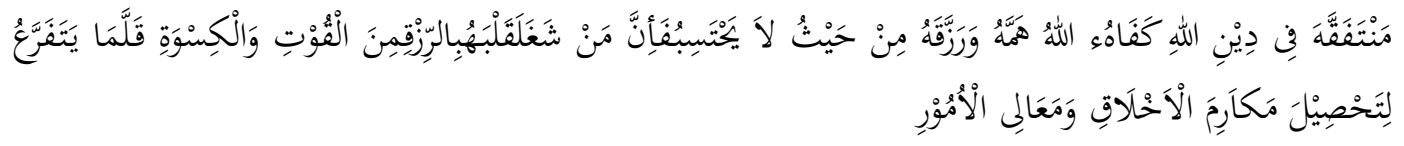

Barang siapa yang mengerti tentang hukum-hukum syara' Agama lsIam, maka Allah Swt. mencukupkan segala apa yang telah di maksuti serta memberi rezeki yang tidak dikira-kira, karena barang siapa yang terlalu sibuk memikirkan tentang rezeki, seperti makanan atau pakaiannya, jelas dia sedikit sekali mempunyai waktu untuk memperoleh hasil budi pekerti yang luhur serta perkara yang mulia. ${ }^{28}$

Mencari IImu adalah ibadah dan bentuk pengabdian yang berjalan di jalan Allah Swt. Jadi dalam dunia pendidikan yang berada di ruang lingkup lsIami, proses belajar (murid, peserta didik, santri) harus fokus mencari lImu, jangan mendahulukan memikirkan hal yang sifatnya duniawi. Namun, di jaman sekarang banyak orang yang menuntut IImu hanya bertujuan untuk mencari uang, bukan karena semata karena Allah. Hal ini akan membuat orang tersebut terjerumus di jalan yang salah sehingga sulit untuk mendapatkan keberkahan.

\section{Kedelapan; Waktu Menuntut lImu}

Menuntut IImu dalam konsep Az-Zarnuji dikatakan bahwasanya dalam menuntut lImu dan mengahasilkannya itu tidak ada waktu terbatas, yakni mulai masih dalam ayunan (bayi) sampai ke liang lahad (kubur). Adapun waktu yang lebih utama untuk belajar adalah masa muda, waktu sahur (waktu menjelang subuh), kemudian antara waktu maghrib dan isya.

${ }^{28} \mathrm{Ibid}, 75$. 
Seorang penuntut IImu hendaknya Ia menggunakan seluruh waktunya untuk belajar. ${ }^{29}$

Atas Uraian tersebut bagian dari konsep yang gampang dicerna oleh akal pikiran. Sebab pada dasarnya tidak ada waktu yang terlambat seseorang dalam mencari IImu, baik muda maupun sudah tua, masih dianjurkan. Seperti halnya pepatah mengatakan, "usia hanyalah waktu, tidak diam seperti batu, berjalan terus berlalu, tak ada batas mencari IImu," pepatah tersebut juga menunjukkan bahwa kebebasan dalam proses berpikir dan mencerna apa yang ada di alam semesta ini. Akantetapi ada juga pepatah yang mengatakan, "belajar di waktu kecil, bagaikan melukis di atas batu, belajar di waktu tua bagaikan melukis di atas air," pepatah tersebut hanya perbandingan bahwa belajar di masa kecil itu akan abadi dan selalu ingat, serta mempunyai daya hafalan yang kuat, sedangkan kalau sudah tua, akan cepat hilang.

\section{Kesembilan; Belas Kasih dan Nasihat}

Seorang penuntut IImu hendaknya memiliki rasa kasih sayang, suka memberi nasihat dan tidak memiliki sifat dengki dan iri hati, karena sifat iri hati dan dengki adalah sifat yang membahayakan dan tidak ada manfaatnya. Seperti apa yang dituturkan dalam syair ini:

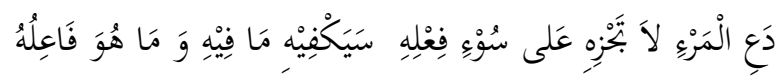

Artinya: Biarkan dia, jangan membalas perbuatan buruknya atas dirimu cukuplah apa yang ia lakukan dan hal itu akan menimpa dan kembali pada dirinya sendiri. ${ }^{30}$

Perlu diketahui bahwasanya orang yang menuntut IImu itu tidak membalas setiap perbuatan buruk orang lain terhadapnya, selain itu seorang alim hendaknya tidak usah turut melibatkan diri dalam pertikaian dan perdebatan sengit dengan orang lain, karena hal itu hanya membuangbuang waktu saja. Dikatakan bahwa orang yang berbuat kebajikan akan dibalas karena kebijakannya, sedangkan orang yang berbuat buruk akan diberatkan oleh keburukannya sendiri. Begitu pula pendidikan lsIam dalam mencari IImu, belas kasih dan nasihat sangat dibutuhkan. Sebagai pendidik dan peserta didik juga harus memperhatikan hal itu, karena

${ }^{29}$ Ibid, 81.

${ }^{30}$ Az-Zarnuji, Pentingnya Adab Sebelum Ilmu, 130-140. 
kerendahan hati yang mampu menerima dan melakukan kedua hal tersebut.

\section{Kesepuluh; Mengambil Manfaat/Memetik Pelajaran}

Seorang penuntut IImu hendaknya ia bisa memetik pelajaran pada setiap waktunya hingga ia bisa meraih keutamaan. Adapun cara memetik manfaat ialah dengan selalu (setiap saat). ${ }^{31}$ Ash-Shdrusy-Shahid Husammuddin berwasiat kepada Syamsuddin putra beliau, agar setiap hari menghafal sedikit IImu dan sepatah hikmah, karena hal itu mudah dilakukan, dan dalam waktu yang singkat lalu akan menjadi banyak. ${ }^{32}$

Kontekstualnya uraian di atas menunjukkan adanya pengambilan manfaat bagi murid atau pelajar yang sedang mencari IImu. Manfaat di sini harus dilandaskan dengan kepandaiannya untuk bisa mengolah dan memanfaatkan apa yang sudah didapatkan. Setelah itu harus ada timbal balik terhadap dirinya sendiri. Seperti halnya, bisa mengubah pola hidup dari buruk ke baik, dari kotor ke bersih, dan dari sempit ke luas. Hal demikianlah yang bisa dikatakan bahwa pengambilan manfaat dari hasil belajar itu berhasil.

\section{Kesebelas; Wara' Saat Belajar}

Untuk memiliki lImu yang bermanfaat hendaknya seorang penuntut IImu memilki sifat wara', bersifat wara' adalah menjaga dirinya dari hal-hal makruh contohnya, terlalu banyak tidur dan makan sampai sangat kenyang dan tidak banyak membicarakan hal-hal yang kurang berfaedah. ${ }^{33}$

Apa yang disampaikan Az-Zarnuji di atas, menunjukkan harus ada kesungguhan dalam belajar, menghindari adanya hal yang bisa mengganggu konsentrasi. Pembelajaran dalam perspektif lsIam tidak sertamerta belajar saja, akantetapi harus ada kesungguhan dan bisa menahan diri dari gejolak keegoisan yang ada di dalam diri. Kata "wara'” di sini juga

\footnotetext{
31Syekh Az zarnuji, Ta'limul Muta'allim, 89.

${ }^{32}$ Ibid, 91.

${ }^{33}$ Ibid, 102-103.
} 
bisa dikatakan menjaga diri dalam belajar, sehingga kata "wara'" bagian dari hal yang sederhana, namun terasa berat untuk melakukannya.

Di sisi lain harus ada pengamalan-pengamalan atas IImu yang sudah didapatkan, dan harus bisa menghindari hal-hal yang sifatnya malas. Kata "malas" di sini menyepelekan sesuatu yang tidak begitu penting, namun pada dasarnya itu penting, tidak mau bergerak dan bertindak, serta selalu ingin diam. Semasih hal tersebut masih berada di dalam diri pelajar, maka sulit untuk sukses dalam menuntut IImu.

\section{Keduabelas; Daya Ingat dalam Hafalan}

Hal-hal yang bisa mempermudah hafalan adalah kesungguhan, ketekunan, mengurangi makan, shalat malam dan membaca Al-Quran. Adapun faktor yang dapat memepersulit hafalan adalah berbuat maksiat, banyak dosa, susah prihatin, dan selalu memikirkan dunia. Karena dalam masa mencari IImu tidak diperkenankan untuk memikirkan hal yang bersifat duniawi. ${ }^{34}$ Dalam suatu riwayat telah dijelaskan melalui syair;

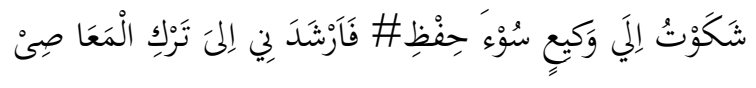

Artinya; aku pernah melaporkan kepada Ustadz waki tentang sulitnya hafalanku kemudian ustadz waki berkata padaku, tinggalkanlah segala perilaku ma'siat

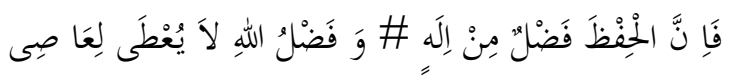

Artinya; Karena sesungguhnya hafalan itu karunia Allah Swt. maka dari itu karunia Allah Swt. tidak diberikan kepada orang yang berbuat ma'siat. ${ }^{35}$

Konteks muatan syair di atas menekankan ketika ingin mempunyai daya ingat yang kuat, harus menghindari maksiat. Maksiat di sini bisa berangkat dari segala hal, seperti mata yang sedang melihat sesuatu yang bukan muhrim, seperti tangan yang melakukan imajinasi yang dilarang, dan juga kuping dalam mendengar hal-hal yang tidak diperbolehkan.

\footnotetext{
${ }^{34}$ Ibid, 104.

35Imam, Az-Zarnuji, Pentingnya Adab Sebelum Ilmu, 151.
} 


\section{Motivasi Belajar Perspektif Az-Zarnuji dalam Hadist dan Al-Qur'an}

Al-Qur'an menyeru manusia untuk meraih keberhasilan di dunia dan akhirat, dalam lsIam dimensi dunia tidak bisa dipisahkan dengan akhirat, karena akhirat adalah tujuan keberhasilan hidup jangka panjang yang bersifat kekal dan abadi. Namun hal itu tidak akan kita sadari tanpa kita mencari IImu dengan sebenar-benarnya seperti yang telah dituturkan oleh Az-Zarnuji.

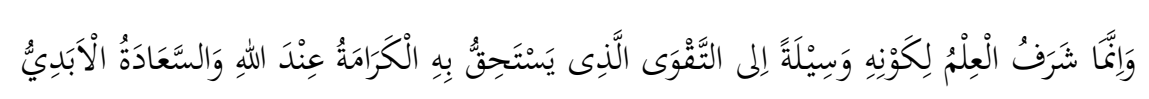

Artinya; Sesungguhnya IImu itu menjadi mulia, lantaran sebagai sarana untuk menuju taqwa kepada Allah Swt. Dengan taqwa. Nabi Adam As. Di berikan kemulian melebihi malaikat dan Mendapatkan hak untuk memperoleh kemuliaan dan kebahagiaan yang abadi disisi Allah Swt. karena memiliki IImu. ${ }^{36}$

Seperti yang telah diwahyukan oleh Allah Swt. Dalam surat Al-Mujadalah ayat 11 .

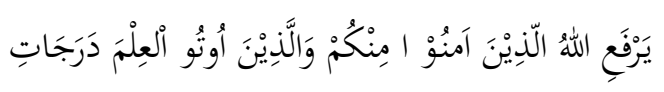

Artinya; Berdirilah kamu, maka berdirilah niscaya Allah akan meninggikan orang-orang yang beriman di antaramu dan orang-orang yang berilmu pengetahuan beberapa derajat, dan Allah Maha Mengetahui apa yang kamu kerjakan.

Tafsir dari ayat tersebut adalah Allah akan mengangkat derajat orang yang berilmu di antara kalian dengan kemuliaan di dunia dan pahala di akhirat. Maka barang siapa yang beriman dan memiliki IImu maka allah akan mengangkat derajatnya dengan keimanannya itu dan mengangkat derajatnya dengan lImunya pula, dan salah satu dari itu adalah Allah mengangkat derajat mereka dalam majlis-majlis IImu.

Di riwayat darilbnu Asakir diriwayat dari Ibnu Abbas dari Rasulullah SAW.

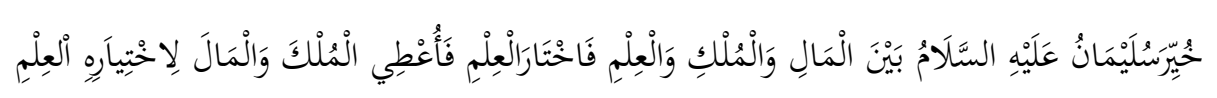

36Syaikh Az zarnuji, Ta'limul Muta'allim, 4. 
Di perintahkan memilih Nabi Sulaiman As. antara harta, kerajaan (tahta) dan IImu, kemudian Allah Swt. memberikan Nabi Sulaiman memilih IImu dari IImu tersebut Nabi Sulaiman mendapatkan kerajaan (tahta) dan harta karena memilih IImu. ${ }^{37}$

Dari beberapa keterangan di atas dapat disimpulkan bahwa betapa pentingnya seseorang untuk menuntut IImu karena IImu adalah penentu dalam kehidupan seseorang seperti yang telah dikatakan oleh Syaikhul lsIam yang dikutip oleh Az-Zarnuji dalam kitabnya.

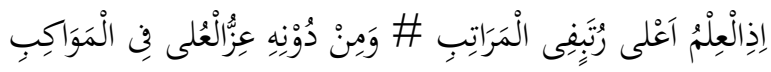

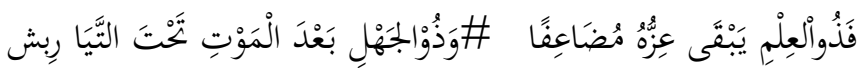

Artinya: IImu itu paling tinggi derajat kepangkatannya dibanding derajat lainnya. Adapun derajat kepangkatan selain IImu adalah hanya untuk pergaulan. Karena orang yang mempunyai IImu itu kemuliaannya k ganda dan terus menerus yakni selamanya. Adapun orang yang ketika sudah mati, maka ia akan terkulai segalanya dalam tanah. ${ }^{38}$

\section{Daftar Pustaka}

Amna Emda. 2017. Kedudukan Motivasi Belajar Dalam Pembelajaran. Banda Aceh: UIN Ar-Raniry.

Azwar, Saifuddin. 2005. Metode Penelitian. Yogtakarta: Pustaka Pelajar.

Az-Zarnuji. 2019. Pentingnya Adab Sebelum IImu, Surakarta: PT Aqwam Media Perofetika.

Basir Abd. 2015. Pendidikan Keluarga Qur'ani. Banjarmasin: Aswaja Pressindo.

Beni, Ahmad, saebani. 2010. IImu Akhlak. Bandung: CV Pustaka Setia.

Hidayat, Rahmat. 2016. lImu Pendidikan lsIam. Medan: LPPPI.

\footnotetext{
37Zainuddin Al-Ma'bari Al-Malibar,Irsyadul Ibad, (Beirut: Dar Al- Kutub, 2011), 15.

${ }^{38}$ Syaikh AZ Zarnuji, Ta'limul Mutaallim, 48.
} 
Imam Az Zarnuji. 2019. Pentingnya Adab Sebelum lImu. Solo: PT AQWAM MEDIA PROFETIKA.

Imam, Az-Zarnuji. 2005. Ta'lim wa Muta'allim Pedoman belajar pelajar dan, Surabaya: AL-HIDAYAH.

Isnaeni. 2019. Konseling Behavioral Berbasis Kitab Ta'limul Muta'allim Untuk Meningkatkan Motivasi Belajar Seorang , Skripsi. Surabaya I SunanAmpel,.

Langgulung, Hasan. 1987. Asas-Asas Pendidikan lsIam. Jakarta: Pustaka AlHusna.

Sardiman, A.M. 2012. Interaksi dan motivasi Belajar Mengajar. Jakarta: PT Raja Grafindo Persada, Jakarta.

Slameto. 2002.Belajar dan Faktor-faktor yang Mempengaruhinya. Salatiga: PT RINEKA CIPTA.

Syekh Az Zarrnuji.1963.Ta'lim wa Muta'allim. Magelang: Maktabah Menara Kudus.

Zainuddin 2011. Al- Ma'bari Al-Malibar, Irsyadul Ibad. Beirut: Dar AlKutub. 